\title{
HAZARD ANALYSIS OF EXOTIC PATHOGENS OF POTENTIAL THREAT TO EUROPEAN FRESHWATER CRAYFISH.
}

\author{
B.F. EDGERTON (1)
}

(1) UMR 5098, CNRS / IFREMER / UM2, DRIM CC80, Place Eugène Bataillon, 34095 MONTPELLIER Cedex 05, France.

Current address: Institute of Zoology, Fish Biology and Fish Diseases, Veterinary Faculty, University of Munich, Kaulbachstr. 37, $80539 \mathrm{MUNICH}$, Germany.

E-mail : brettedgerton@ hotmail.com

Reçu le 14 janvier 2002

Received 14 January, 2002

Accepté le 14 octobre 2002

Accepted 14 October, 2002

\begin{abstract}
Managers, scientists, fishermen and farmers who work with freshwater crayfish understand clearly the severe affects that the introduction of an exotic pathogen can have on freshwater crayfish populations. This acute awareness is due to the severe impact on native European freshwater crayfish of the introduction of crayfish plague fungus Aphanomyces astaci. This issue has been thoroughly covered in previous reviews. The potential impact of other pathogens on European freshwater crayfish has not been addressed. This paper presents a hazard analysis of pathogens of freshwater crayfish exotic to Europe, which is the first step of import risk analysis.
\end{abstract}

Key-words: European freshwater crayfish, exotic disease, hazard analysis, Government biosecurity policy.

\section{ANALYSE DE RISQUE DES PATHOGÈNES EXOTIQUES REPRÉSENTANT UNE MENACE POTENTIELLE POUR LES ÉCREVISSES EUROPÉENNES.}

\section{RÉSUMÉ}

Les aménageurs, les scientifiques, les pêcheurs et les éleveurs qui travaillent avec les écrevisses comprennent clairement les effets sévères que l'introduction d'un pathogène exotique peut avoir sur les populations d'écrevisses. Cette conscience aiguë est due à l'impact grave sur les écrevisses européennes indigènes de l'introduction du champignon de la peste des écrevisses (Aphanomyces astaci). Ce problème a été complètement exposé dans des revues précédentes. L'impact potentiel d'autres microbes pathogènes sur les écrevisses européennes n'a pas été examiné. Cet article présente une analyse de risque des pathogènes des écrevisses non encore présents en Europe, qui est la première étape de l'analyse de risque d'importation.

Mots-clés: écrevisses européennes, pathogène exotique, analyse de risque, politique de biosécurité du gouvernement. 


\section{INTRODUCTION}

The introduction of the crayfish plague fungus Aphanomyces astaci into Europe with American freshwater crayfish species is perhaps the most commonly quoted case of exotic disease incursion in the field of aquatic animal pathobiology. This is due to the very major impact that this pathogen has had on the native European freshwater crayfish species. The spread and effects of $A$. astaci in European crayfish populations has been comprehensively studied and there are many excellent reviews on the subject (ALDERMAN, 1986 is one example).

Whilst the crayfish plague incursion has done much to emphasise the importance of biosecurity and the impact that exotic disease can have on native populations, the severity of crayfish plague has skewed research effort in the field of crayfish pathology. Consequently, other areas of research have not received the attention that experiences with other animals would suggest they deserve. Moreover, as many diagnosticians and researchers have concentrated on detecting $A$. astaci, fundamental diagnostic techniques such as histopathology and bacteriology have been under-utilised (EDGERTON, 2000). It is for this reason, perhaps, that infections in freshwater crayfish by viruses and rickettsialike organisms (RLO) were not reported until quite recently. These pathogens frequently cause severe disease in captive and/or cultured crustaceans, and have been reported as the cause of mortality of Australian freshwater crayfish species in semi-intensive aquaculture (OWENS et al., 1992; KETTERER et al., 1992; EDGERTON et al., 1995; JONES and LAWRENCE, 2001). Of particular relevance to this paper, the first description of a natural viral infection in an European freshwater crayfish was published less than ten years ago (EDGERTON et al., 1996), and infections by RLOs have not yet been reported. It is therefore appropriate to conclude that our current knowledge of diseases of freshwater crayfish is poor relative to many other aquatic animals, and this is especially true for wild populations of freshwater crayfish.

In the companion article (EDGERTON, 2002) to this one, the process of import risk analysis was reviewed with emphasis on freshwater crayfish. The first step in import risk analysis is hazard analysis, and following is a brief hazard analysis for freshwater crayfish importation into Europe. Interested parties would be well advised to view the policy documents developed by Agriculture, Fisheries and Forestry - Australia (AFFA) for an IRA on freshwater crayfish which was in process at the time of writing (www.affa.gov.au). A synopsis of diseases of freshwater crayfish (EDGERTON et al., 2002), which was produced as a resource document for the AFFA freshwater crayfish IRA, should also be consulted.

\section{VIRUSES}

Viruses have caused major losses in farmed crustacean populations around the world (LIGHTNER, 1996). Viruses were unknown in freshwater crayfish until the 1990s, but many viruses have been discovered in freshwater crayfish in the last decade (EDGERTON, 1999). Some of the crayfish viruses have been associated with chronic or epizootic mortality in the species in which they were described (EDGERTON et al., 1995; JONES and LAWRENCE, 2001). However, none of the viruses reported to infect natural populations of freshwater crayfish have been associated with widespread epizootic mortality. There have been no studies on these viruses to determine their potential host range even among species in the same genera. Therefore, it is essentially impossible with the currently available data to determine whether these viruses would cause a significant effect on European freshwater crayfish if introduced.

White spot syndrome virus (WSSV) is perhaps the most devastating of all crustacean viruses. WSSV has a very wide host range and has infected almost all decapods that have been experimentally exposed to it (AQIS, 2000; CORBEL et al., 2001). 
Transmission trials with freshwater crayfish show that they are highly susceptible to infection by WSSV and they typically experience rapid mortality soon after exposure (Figure 1). Thorough comparisons to other crustaceans of their susceptibility to WSSV are impossible as there are no permanent crustacean cell lines to titrate the number of infectious particles to which the animals were exposed. However, qualitative indications from these trials suggest that their susceptibility to white spot disease (WSD) varies between species of freshwater crayfish, and that, generally, they are marginally less susceptible to WSD than are prawns (RICHMAN et al., 1997; CORBEL et al., 2001). To this point, Astacus leptodactylus is the only native European freshwater crayfish species for which there is published data on its susceptibility to WSSV (CORBEL et al., 2001).

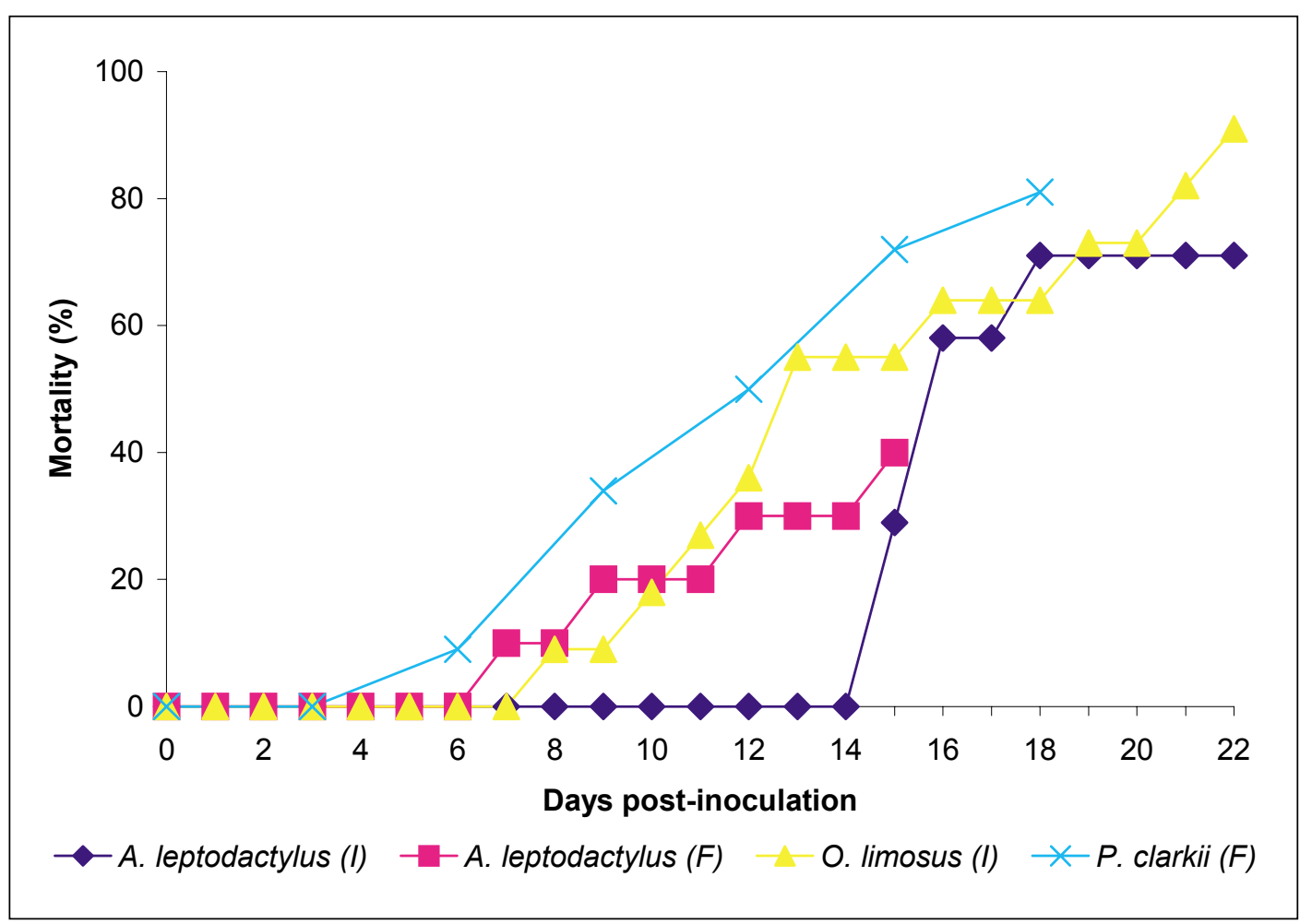

Figure 1

Mortality curves for freshwater crayfish exposed to white spot syndrome virus (WSSV). (I) = injected with WSSV; (F) = fed tissues infected with WSSV (data from CORBEL et al., 2001; WANG et al., 1998).

Figure 1

Courbe de mortalité pour les écrevisses d'eau douce exposées au white spot syndrome virus (WSSV). (I) = WSSV injecté ; $(F)=$ alimentation avec des tissus atteints de WSSV (données de CORBEL et al., 2001 ; WANG et al., 1998).

Though WSSV has been associated with panzootics in prawn aquaculture, there are no reports associating WSSV with epizootics in wild crustaceans even though WSSV is known to occur at a high prevalence in wild prawns in regions where WSSV was panzootic in aquaculture. WSD is listed by the OIE as a Notifiable Disease (OIE, 2001). In fact WSD is the only OIE listed disease to which freshwater crayfish are susceptible which is exotic to Europe. WSSV may cause serious losses if it were established in freshwater crayfish populations in Europe. 


\section{BACTERIA}

A variety of Gram positive and Gram negative bacteria inhabit the external exoskeleton, gut and frequently the haemolymph of freshwater crayfish (THUNE, 1994; EVANS and EDGERTON, 2002; EDGERTON et al., 2002). Bacteria are usually considered to be secondary or opportunistic pathogens of freshwater crayfish (EVANS and EDGERTON, 2002). Some species of bacteria are known to be pathogens of stressed freshwater crayfish. For example, Vibrio mimicus has been associated with mortality in highly stressed freshwater crayfish in USA (THUNE et al., 1991) and Australia (EAVES and KETTERER, 1994). Based on published data, there is no reported exotic Gram negative or Gram-positive bacterium which obviously represents a serious threat to European freshwater crayfish.

At least two prokaryotic rickettsia-like organisms have been reported to infected freshwater crayfish (KETTERER et al., 1992; OWENS et al., 1992; JIMÉNEZ and ROMERO, 1997; EDGERTON and PRIOR, 1999). One of the RLOs is known to cause serious disease in Cherax quadricarinatus in farms. There are no data on the potential host ranges of these RLOs, and they may or may not represent a significant risk to exposed native European freshwater crayfish.

\section{FUNGI}

With the exception of $A$. astaci which is already widespread in Europe, fungi are typically considered to be secondary or opportunistic pathogens of freshwater crayfish (AQIS, 1999). Nonetheless, several Fusarium spp. and Saprolegnia parasitica have been associated with disease in freshwater crayfish, most frequently in Europe (ALDERMAN and POLGLASE, 1985; CHINAIN and VEY, 1987a, b, 1988; ALDERMAN and POLGLASE, 1988; DIÉGUEZ-URIBEONDO et al., 1994). There are no reported exotic fungi which represent an obvious and serious threat to European freshwater crayfish.

\section{PROTOZOANS}

Microsporidians are frequently considered to be important pathogens of freshwater crayfish (ALDERMAN and POLGLASE, 1988; EDGERTON et al., 2002). This may be a result of the ease with which they can be detected in crayfish populations due to the very obvious clinical sign of whitening of the musculature. The taxonomy of microsporidians is unclear. Consequently, the geographic distributions of species are also unclear. It is likely that there are freshwater crayfish-infecting microsporidians which are exotic to Europe and these may represent a significant risk if introduced.

Many other protozoans have been reported as potential pathogens or commensals of freshwater crayfish (ALDERMAN and POLGLASE, 1988; EVANS and EDGERTON, 2002; EDGERTON et al., 2002). The potential pathogens are typically opportunistic. Besides microsporidians, no exotic protozoans present an obvious significant risk to European freshwater crayfish if introduced.

\section{DRIPS CLADE}

The taxonomic significance of the morphotypes of Psorospermium is unclear. However, there are morphotypes which are considered to be exotic to Europe (HENTTONEN et al., 1994; VOGT, 1999; EVANS and EDGERTON, 2002). Given that Psorospermium has been associated with disease in farmed freshwater crayfish (SÖDERHÄLL, 1988; EDGERTON et al., 1995), exotic Psorospermium morphotypes or species may represent a significant risk to European freshwater crayfish if introduced. 


\section{METAZOANS}

A multitude of metazoans are commensals or parasites of freshwater crayfish (ALDERMAN and POLGLASE, 1988; EVANS and EDGERTON, 2002; EDGERTON et al., 2002). None of these are considered to be significant pathogens of the freshwater crayfish hosts from which they were described, and therefore present an obvious significant risk to European freshwater crayfish if introduced. However, concerns have been expressed about the potential loss of biodiversity caused by co-translocation of competitor metazoan commensals with freshwater crayfish (MITCHELL and KOCK, 1988; AVENANTOLDEWAGE, 1993; XYLANDER, 1997; QUAGLIO et al., 1999).

\section{CONCLUDING REMARKS ON THE ASSESSMENT OF POTENTIAL HAZARDS TO EUROPEAN FRESHWATER CRAYFISH}

The confidence that can be placed in the outcome of an IRA for freshwater crayfish is severely curtailed by a paucity of data on their pathogenic fauna; this paucity of data also presents some practical difficulties in writing the IRA. There is very little published data on the overall types and occurrence of pathogens in freshwater crayfish in Europe and elsewhere. This information is vital if a high level of confidence is to be placed in the outcome of the IRA, as the analyst must consider both the occurrence of pathogens in the importing country or region as well as in the exporting country. This information must be gathered by health surveys utilising diagnostic techniques appropriate for detecting a wide range of pathogens, and the most important technique is histopathology. Histopathology must also be utilised when investigating the cause of mortality in freshwater crayfish populations. If other more specific diagnostic techniques are utilised, such as bacterial or fungal cultures, many pathogens such as viruses, rickettsiae, protozoans and others will not be detected.

Many pathogens of freshwater have simply been reported with basic descriptions of their morphology and few studies have been conducted on their relationships with other described pathogens. This in turn has resulted in confusion over the geographic range of many freshwater crayfish pathogens. The following are just a few important examples which have all been reported from several continents - the microsporidians and most importantly Thelohania contejeani, Psorospermium spp. and the intranuclear bacilliform viruses. Moreover, there is extremely limited data on host range and the modes of transmission for most pathogens of freshwater crayfish. Clearly these data are paramount for IRA.

The levels of risk posed by most individual pathogens of freshwater crayfish are difficult, if not impossible, to accurately assess with the currently available data. Such an analysis is beyond the scope of this paper. Nonetheless, there are several general points that can be made here in relation to levels of risk and risk management. If a pathogen occurs in an area/population, then the importation of live animals does represent a greater risk than does importation of dead animals. This is due to the potential for the animal to escape and live in the natural environment and continually or periodically shed that pathogen. This is dependant on the suitability of the environment for the imported species. It is unlikely that a freshwater crayfish species native to the tropics would survive for long in the wild in Scandinavia, or for the opposite to occur. In these cases, the risk may be considered to be similar to importing dead animals except that there is an additional exposure pathway to consider - that the animal is perhaps capable of escaping into the wild even though it would die soon thereafter. In relation to the risks associated with importing dead freshwater crayfish, most pathogens within tissues or on external surfaces will be destroyed by chilling, freezing and/or cooking. 
Risk management options for importing live freshwater crayfish include surveillance programs for disease in conjunction with zoning policies so that animals could only be imported into a country or zone free of a pathogen from another country or zone also free of that pathogen. Importantly, freshwater crayfish breed readily in captivity, and moreover, eggs in early stages of development may be removed from brooding females and hatched separately from the mother. Few pathogens of freshwater crayfish are likely to be transmitted within the egg. Therefore, juveniles produced in this manner are likely to be infected by few or no pathogens when done in conjunction with good hygiene controls such as disinfection of the surface of the eggs and incubation in clean water. Specific pathogenfree crayfish have been produced by this method (EDGERTON and OWENS, 1997) and it is likely to be a very effective and, therefore, valuable risk management measure.

\section{REFERENCES}

ALDERMAN D.J., 1986. Geographical spread of bacterial and fungal diseases of crustaceans. Revue Scientifique et Technique Office International des Epizooties, 15 (2), 603-632.

ALDERMAN D.J., POLGLASE J.L., 1985. Fusarium tabacinum (Beyma) Gams. as a gill parasite in the crayfish, Austropotamobius pallipes Lereboullet. Journal of Fish Diseases, 8 (2), 249-252.

ALDERMAN D.J., POLGLASE J.L., 1988. Pathogens, parasites and commensals. In : Freshwater crayfish - biology, management and exploitation, HOLDICH D.M. and LOWERY R.S. (Eds.), 167-212. Croom Helm, Sydney.

AQIS, 1999. Non Viable Freshwater Crayfish Import Risk Analysis: Technical Issues Paper. AQIS, Canberra.

AQIS, 2000. Prawns and Prawn Products: Draft Import Risk Analysis Paper. Canberra, Australia.

AVENANT-OLDEWAGE A., 1993. Occurrence of Temnocephala chaeropsis on Cherax tenuimanus imported into South Africa, and notes on its infestation of an indigenous crab. South African Journal of Science, 89 (9), 427-428.

CHINAIN M., VEY A., 1987a. Comparative studies on strains of Fusarium solani parasitic for crayfish or isolated from other hosts. Freshwater Crayfish, 7, 179-186.

CHINAIN M., VEY A., 1987b. Infection caused by Fusarium solani in crayfish Astacus leptodactylus. Freshwater Crayfish, 7, 195-202.

CHINAIN M., VEY A., 1988. Experimental study of Fusarium solani: infections in Astacus leptodactylus and Pacifastacus leniusculus (Crustacea, Decapoda). Diseases of Aquatic Organisms, 5 (3), 215-223.

CORBEL V., ZUPRIZAL, SHI Z., HUANG Z., ARCIER J.M., BONAMI J.R., 2001. Experimental infection of European crustaceans with white spot syndrome virus (WSSV). Journal of Fish Diseases, 24, 377-382.

DIÉGUEZ-URIBEONDO J., CERENIUS L., SÖDERHÄLL K., 1994. Saprolegnia parasitica and its virulence on three different species of freshwater crayfish. Aquaculture, 120, 219-228.

EAVES L.E., KETTERER P.J., 1994. Mortalities in red claw crayfish Cherax quadricarinatus associated with systemic Vibrio mimicus infection. Diseases of Aquatic Organisms, 19 (3), 233-237.

EDGERTON B.F., 1999. A review of freshwater crayfish viruses. Freshwater Crayfish, 12, 261-278.

EDGERTON B.F., 2000. A compendium of idiopathic lesions observed in redclaw freshwater crayfish Cherax quadricarinatus (von Martens). Journal of Fish Diseases, 23 (2), 103-114.

EDGERTON B.F., 2002. A review of international biosecurity policy development in relation to movements of freshwater crayfish. Bull. Fr. Pêche Piscic., 367, 805-812. 
EDGERTON B.F., OWENS L., 1997. Age at first infection of Cherax quadricarinatus by Cherax quadricarinatus bacilliform virus and Cherax Giardiavirus-like virus, and production of putative virus-free crayfish. Aquaculture, 152 (1-4), 1-12.

EDGERTON B.F., PRIOR H.C., 1999. Description of a hepatopancreatic rickettsia-like organism in the redclaw crayfish, Cherax quadricarinatus. Diseases of Aquatic Organisms, 36 (1), 77-80.

EDGERTON B.F., OWENS L., HARRIS L., THOMAS A., WINGFIELD M., 1995. A health survey of farmed redclaw crayfish Cherax quadricarinatus (von Martens), in tropical Australia. Freshwater Crayfish, 10, 322-338.

EDGERTON B.F., PAASONEN P., HENTTONEN P., OWENS L., 1996. Description of a bacilliform virus from the freshwater crayfish, Astacus astacus. Journal of Invertebrate Pathology, 68 (2), 187-190.

EDGERTON B.F., EVANS L.H., STEPHENS F.J., OVERSTREET R.M., 2002. Synopsis of freshwater crayfish diseases and commensal organisms. Aquaculture Annual Review of Fish Diseases, 206, 57-135.

EVANS L.H., EDGERTON B.F., 2002. Pathogens, parasites and commensals. In : Biology of Freshwater Crayfish, HOLDICH D.M. (ed.), 377-438. Blackwell Science Ltd, Oxford, England.

HENTTONEN P., HUNER J.V., LINDQVIST O.V., 1994. Occurrence of Psorospermium sp. in several North American crayfish species, with comparative notes on Psorospermium haeckeli in the European crayfish, Astacus astacus. Aquaculture, 120 (3-4), 209-218.

JIMÉNEZ R., ROMERO X., 1997. Infection by intracellular bacterium in red claw crayfish, Cherax quadricarinatus (Von Martens), in Ecuador. Aquaculture Research, 28, 923-929.

JONES J.B., LAWRENCE C.S., 2001. Diseases of yabbies (Cherax albidus) in Western Australia. Aquaculture, 194 (3-4), 221-232.

KETTERER P.J., TAYLOR D.J., PRIOR H.C., 1992. Systemic rickettsia-like infection in farmed freshwater crayfish, Cherax quadricarinatus. In: Diseases in Asian Aquaculture I, SHARIFF M., SUBASINGHE R.P. and ARTHUR J.R. (Eds.), 173-179. Fish Health Section, Asian Fisheries Society, Manila, Philippines.

LIGHTNER D.V., 1996. Handbook of Shrimp Pathology and Diagnostic Procedures for Diseases of Cultured Penaeid Shrimp. World Aquaculture Society, Baton Rouge, Louisiana.

MITCHELL S.A., KOCK D.J., 1988. Alien symbionts introduced with imported marron from Australia may pose a threat to aquaculture. South African Journal of Science, 84 (11), 877-878.

OIE, 2001. International Aquatic Animal Health Code. Office International des Epizooties.

OWENS L., MUIR P., SUTTON D., WINGFIELD M., 1992. The pathology of microbial diseases in tropical Australian Crustacea. In: Diseases in Asian Aquaculture I, SHARIFF M., SUBASINGHE R.P. and ARTHUR J.R. (Eds.), 165-172. Fish Health Section, Asian Fisheries Society, Manila, Philippines.

QUAGLIO F., TRENTINI M., MAZZONI D., NOBILE L., 1999. Observations on temnocephalid (Platyhelminthes) ectosymbionts in Australian freshwater crayfish (Cherax destructor Clark) introduced into Northern Italy. Freshwater Crayfish, 12, 335-342.

RICHMAN L.K., MONTALI R.J., NICHOLS D.K., LIGHTNER D.V., 1997. A newly recognized fatal baculovirus infection in freshwater crayfish. Proceedings of the American Association of Zoo Veterinarians, 1997. Abstracts.

SÖDERHÄLL K., 1988. Fungal parasites and other diseases on freshwater crayfish. In : Raputalous 2000, Keski-Suomen Kalastuspiin Kalastustoimisto, KOVANEN J. and LAPPALAINEN R. (Eds.), 23-46. Tiedotus, Jyväskylä, Finland.

THUNE R., 1994. Diseases of Louisiana crayfish. In : Freshwater Crayfish Aquaculture in North America, Europe, and Australia, HUNER V. (ed.), 117-156. Food Products Press, New York. 
THUNE R.L., HAWKE J.P., SIEBELING R.J., 1991. Vibriosis in the red swamp crawfish. Journal of Aquatic Animal Health, 3, 188-191.

VOGT G., 1999. Diseases of European freshwater crayfish, with particular emphasis on interspecific transmission of pathogens. In: Crayfish in Europe as Alien Species: How to Make the Best of a Bad Situation, GHERARDI F. and HOLDICH D.M. (Eds.), 87-103. A.A. Balkema Publishers, Rotterdam.

WANG Y.C., LO C.F., CHANG P.S., KOU G.H., 1998. Experimental infection of white spot baculovirus in some cultured and wild decapods in Taiwan. Aquaculture, 164 (1-4), 221-231.

XYLANDER W.E.R., 1997. Epidermis and sensory receptors of Temnocephala minor (Plathelminthes, Rhabdocoela, Temnocephalida): an electron microscope study. Zoomorphology, 117, 147-154. 